\title{
Development of Integration Education Model Pela-Gandong Local Based on Local Content in Primary Schools in Ambon City
}

\author{
Beatrix J.M. Salenussa, Suriani, Yufiati, Nova M. Mataheru
}

\begin{abstract}
This study aims to develop abased social integration education model Pela-Gandong as a local content formed through the togetherness of life of the brothers based on kinship values and customary institutions in the context of cultural local wisdom in Maluku. The implementation of the development of this model was based on the desire to recognize, maintain and preserve Maluku culture as an ancestral heritage, which had experienced the shock of harmony in the lives of brothers due to the Maluku conflict in 1999-2004, so through Pela-Gandong based social integration education in Maluku it can be used as a cultural instrument in the intellectual life of the nation but also as an effort to maintain the nobility of the values of the nation's own culture. This study uses a research development method $(R$ $\& D)$ using collaboration from the learning design model Borg and Gall with the ADDIE model (Analysis-Design-Develop-Implement-Evaluate), which produces based local content learning products Pela-Gandongas a learning resource local contents of the Maluku region that are intended for elementary school students with the theme "Beautiful Togetherness Pela-Gandong", which refers to the 2013 curriculum used in Indonesia. The target of this study was fourth grade students (four) at SD Inpres Latta, Baguala-Ambon District. The results of this study indicate that the development of based social integration education models is Pela-Gandong- very effective to be used by fourth grade elementary school students as a local content of learning which is shown through the effectiveness of learning products using minimum completeness criteria (KKM), so that Pela-Gandong based social integration education is very relevant for fourth grade elementary school students not only as a local content in introducing Maluku culture, but more than that, namely as a cultural instrument that is effective in revitalizing and transforming contextual cultural values based on local wisdom in Maluku.
\end{abstract}

Key Words Model Development, Social Integration Education, Pela-Gandong, Local Content

\section{INTRODUCTION}

The diversity of tribes, languages, customs, races and religions in Indonesia is an advantage but also a challenge that can result in conflict. This explains that in diverse

Revised Manuscript Received on September 22, 2019.

Beatrix J.M. Salenussa, Post-Graduation Departmen of Educational Technology Universitas Negeri Jakarta and Lecturer at Universitas Kristen Indonesia Maluku. beatrixjoan_tp12s3@mahasiswa.unj.ac.id

Suriani, Profesor at Universitas Negeri Jakarta. surianiamrin@gmail.com

Yufiati, Profesor at Universitas Negeri Jakarta. yufiarti@unj.ac.id

Nova M. Mataheru, Teacher at SMA Negeri 11 Ambon-Maluku. nova.mataheru@yahoo.com community interactions in Indonesia, it is not necessarily always going well but often occurs because of the intersection that causes widespread social conflict. The social conflict itself occurs because of differences in interests between the community or some parties that potentially and practically inhibit each other (Chandra, 1992). Therefore, social integration education is very much needed in the process of uniting several elements or elements that exist in society, so that it becomes a single entity even if it takes a long time or not fast, but the process can be an effective cultural instrument to revitalize and transform values the value of local wisdom (local wisdom), as a cultural process that should have an important function to deliver humans in an effort to develop all their potential comprehensively (Triyanto, 2014).

Starting from this thought, humans as cultured individuals must be able to develop their local cultural potential. And through these local cultures various kinds of values and norms can be maintained and preserved. In relation to that, local content education as an educational program in its content and delivery relates to development needs in the local area, such as: conditions in the social environment, in the natural environment, and in cultural environments, need to be taught to students so that it continues through local content this is how character education from the nation's children can be built (Marliana \& Hikmah, 2013).

Continuing efforts to build the character of the nation through education of local content, students can be taught in depth about the diversity of local culture as a consensus of customs and community traditions as one of the cultural treasures that need to be preserved as done in Maluku.

Maluku, which has the wisdom of a diverse local culture, consists of; 117 (one hundred and seventeen) ethnic and sub-ethnic (cultural) groups that spread to 812 (eight hundred and twelve) small and large islands, and 117 (one hundred and seventeen) varieties of local or ethnic languages, have made Maluku as a region that has strength unique and solid customs, as a consensus of customs and traditions of the Moluccan community called Orang Basudara (brothers). The term Orang Basudara (brothers) also basically contains an understanding of the original environment of the people in the Maluku islands who feel that they are brothers, even though they are in various life differences that they have

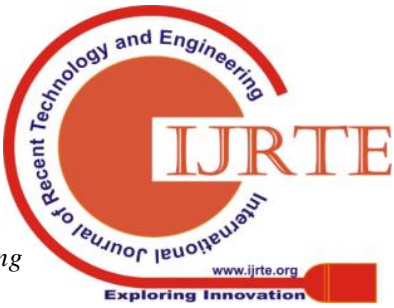


according to the nature of living with cultural ideological values that are more focused on cultural processes as a venue for social integration education with the aim of making local cultural wisdom available as social capital for the people of Maluku and a revitalization movement that intrinsically has an appreciation of cultural values and spirits that are social, traditional and religious ((Watloly, 2012).

Introducing the Maluku cultural traditions such as the Orang Basudara Hydropower viz., Pela-Gandong and other local cultures in Maluku from the beginning for the students at school, actually very useful so that students not only jump directly into concrete situations in their daily lives as children of the Moluccas but also in an effort to build character and identity as children of the country who have moral and brotherly values.

This picture of the identity of a child's country in Maluku is part of the aspect of education that can be used as a cultural instrument that is very effective and significant in educating the younger generation of regions in Maluku to recognize their identity so that noble values are good, manners , disciplined, and polite even more invested.

Looking at various things that have happened in Maluku, such as the SARA social conflict in 1999 - 2004, so that Maluku people, especially in Ambon City experienced a shock of harmony between Orang Basudara, actually wanting to show that the importance of education and culture is not only two inseparable sides but complementary two sides to be used as cultural instruments in fostering the personality of every country child in Maluku, based on the values of society and culture by pointing to the importance of education in an effort to educate the nation's life but also as part of efforts to maintain the nobility of the values of national culture.

In connection with that, learning local content is needed with the aim to provide knowledge, skills, and attitudes to students so they can have a solid insight into the state of the environment and the needs of the community in accordance with the values or rules that apply in their regions and support the continuity of regional development and also national development (Muktadir \& Agustrianto, 2014).

In line with the development of education in Maluku, this might provide convenience in developing the model of social integration education in Pelandongas a local content-based teaching material, in the form of textbooks as the main material that can be used in integrated thematic learning, by presenting various examples - concrete examples according to the conditions of the environment around the students.

The development of the based social integration education model Pela-Gandong- will later feature learning material which can certainly be integrated into several subjects based on the themes in the 2013 curriculum, so that not only is the scope of the local content material given to the Cultural and Craft subjects (SBDP), but also includes other subjects such as; PPKn, IPS, Indonesian Language, Health and Science, with the aim of teaching materials can be used as cultural models in an effort to implement local wisdom as a tool of cultural transformation in contextualization but also in efforts to preserve, preserve and preserve the values of cultural traditions in the learning process not only happens in schools, but also involves parents and the community in related environments.

\section{Literature REVIEW}

\section{A. Concept of Model Development}

In the concept of model development, in general the model can be understood as a complete picture of something very complex and made in a simplified form, so that it can be said as a pattern that is made or produced. This gives the understanding that the model is a miniature of the real conditions and is needed to help understand the complexity of something in order to be able to follow the stages, steps and procedures for a purpose.

For developers in the world of education, the model is very important, because it can be a reference for the development process that will be carried out. With regard to the model, there are several views and opinions expressed by experts in the field of education and learning about the model, including: (1) The view (Gustafson \& Branch, 2002:1). which states that: "a model is a simple representation of more complex forms, processes and functions of physical phenomena or ideas. A model is a simple representation of more complex forms, processes and functions related to the physical or ideas, (2) Weil \& Joice, (1978:2). which states that "a model of teaching consists of guidelines for designing educational activities and environments ."A teaching model contains guidelines for designing educational and environmental activities. Besides that, "a model includes a rationality, a theory that justifies and describes what it is good for and why" (Weil \& Joice, 1978). A model includes the rationale, the theory that justifies and explains why it is good and for what it is done, (3) Richey, Klein, \& Tracey, (2011:8-9). which states that "the model of implies a representation of reality is presented with a degree of structure and order, and models are typically idealized and simplified views of reality ". The model is a representation of reality that is presented in a structured and orderly level, the ideal model is usually simplified by the view of reality, (4) Smaldino, Lowthe, \& Russel, (2011:283), which suggests that the model is a representation of three real objects. It is clear that a model may be bigger, smaller, or the same size as the object it represents. The model may be very detailed or simplified for teaching purposes. The model can also provide learning experiences that real objects cannot do, (5) Smith, Hedges, \& Schankat, (2010:73), a model is a mental picture that helps a person understand something that cannot be seen and experienced directly. (model is a mental picture that helps a person to understand something that cannot be seen and experienced firsthand),(6) Smith \& Ragan, (2005:11), which states that: "The model presented in the figure will assist you in building a mental framework, a scaffold, which should help you learn from critical principles, your mastery of which will make the outlines of the model presented in the picture will help you in 
building a mental framework, scaffolding, which will help you learn important principles, your mastery in making draft outlines. which is not original and open to modify and change as needed. Smith and Ragan's opinion in the concept of this model serves to help other parties in developing mindsets, inspiring others in understanding important principles in a development activity (Smith \& Ragan, 2005).

Furthermore, in categorizing the models, the model itself has two categories: micro morphs and perimorphs. Micro morphs are models in the form of objects or physical and visual imitation such as a form of computer simulation or a form of small-scale objects from the shape of a real large object. While perimorphs are symbolic models that are used usually on verbal descriptions (Richey et al., 2011).

The category perimorphs itself can take the form of one of three models, namely as a conceptual model, procedural model, and mathematical model. In theoretical description, the conceptual model is general and abstract in describing the views on reality and synthesis of a study supported by limited experience or data. For example, for example; face to face from learning systems, or interactive learning based on information and communication technology. Procedural models, steps used in doing work for example; step-by-step instructional design, research and development cycle, syntax-transactional inquiry learning, problem-based learning syntax(Problem Based Learning), as well as constructivism based learning syntax. Whereas for mathematical models usually form a formula to describe the relationship between various components or factors for example; by using the Mastery Learning, formula correlation Alpha Cronbach formula or other formulas that can be used to show productivity.

In addition to the three categories of models described above, there are also models that are categorized into 4 parts, namely: 1) classroom ID models, 2) product development models, 3) systems development models, 4) organization development models ((Gustafson \& Branch, 2002).

Model development is actually needed to help understand the complexity of something, so that it can follow stages, steps, and procedures for a purpose. The model is not just a visualization, but also a guide and reference for some parties who have the desire to pursue the field of development in the world of education. Apart from the opinions and views of some experts about the model, the development itself is more centered on efforts to improve things to be superior to before.

According to Raiser \& Damsay (2007:4), development is a systematic approach in the design, production, evaluation, and utilization of a complete learning system, covering all the appropriate system components. (Development of systematic approach in the design, production, evaluation, and utilization of a comprehensive learning system, including all components of the system right). Thus the description of the model development is a complete picture and real complexity in the form of learning so that it can refer to one category if it is based on research and development in the whole process from beginning to end, so the development of learning models can be grouped by shape.
The function of developing the model itself is as a communication and guidance tool in planning activities to be carried out in management and decision making. It is clear that by understanding and following each step and procedure, it will rationally contain models and theories that can justify that what will be done is the best. The point is that in the development of a model of complexity of a model besides considering rationality and theory, the model of course contains steps and procedures as well as step by step to be passed.

\section{B. Pela-Gandong-Based Social Integration Education as Local Content in School Learning}

Education is a conscious and planned effort to create an active learning atmosphere from each learning process so that students can develop their potential and make the learning process as a means to understand, understand and know something, and more critical in thinking (Wedan, 2016).

Education can also be said as a form of human existential guidance and authentic guidance, when children can learn to recognize their unique identity, can survive, be able to have, and continue and develop the social heritage of the previous generation. Through this, education is then used as an element of culture, because basically the educational process is the essence of the culture itself (Judiani, 2018).

Recognizing the existence of diverse, complex and integrated cultural values, the educational process cannot be seen from just one point of view, but must use a multi-disciplinary view, where culture can be realized through: 1) ideas, ideas, values, norms, regulations and so on. That is, its form is more abstract in nature, cannot be changed or photographed, 2) activities that are patterned from humans in society. The point is that form is often referred to as a social system because it consists of human activities interacting or associating with one another, and 3) objects that are human works or called physical culture that are concrete because they are the real work of humans. (Manuhuttu, Purwiyastuti, \& Widiarto, 2009).

Thus, it can be concluded briefly that education is an educator's effort to channel knowledge to students based on the values that apply in society, and related to that, social education is needed to establish cooperation between individuals, families and communities as a whole, in order to produce values of unity which are upheld together.

Integration derived from the word integrate, which means giving place in a whole, can be interpreted as a combination of certain elements into one round and whole unit. In relation to social life, social integration means making society a unified whole (Dewi, 2007). So that it can be said that social integration is a process of adjustment among the most different elements so as to produce a harmonious pattern of life that can function for the community.

Social integration as one of the positive impacts of social change shows that social integration actually arises due to natural disasters and social conflicts, which illustrate the form of community solidarity

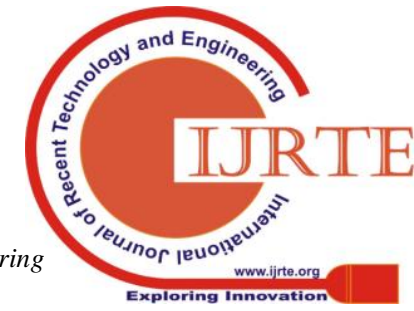


as a very important togetherness so as not to be divided and pitted against by other parties (Rosana, 2011). The positive impact of social change is what then shows an increase in the bonds of solidarity between individuals as happened in Maluku after the conflict which later made Pela-Gandong a form of solidarity to increase the bond of brotherhood to avoid conflict but also as a safety valve conflict, where integration social is then interpreted as a form of solidarity that occurs between mankind but also as a process of unification of social elements in order to achieve harmonious social unity and harmony for social life.

Learning from the cultural life of the Moluccas arranged in a strong traditional life pattern and held with a philosophy that is typical of Maluku, namely the philosophy of the people of Basudara as a form of local wisdom of children of the country in Maluku which is full of wealth of life values that are intertwined and uniting the people of Maluku in the reality of their rich differences, the forms of local wisdom from the Maluku community need to be preserved and preserved.

In the view of Maluku culture according to Hasanah, Ulfatin, \& Wiyono (2017) state that:

"This diversity is reflected upon the variety of languages and accents in Maluku. Even though they have high diversity, they share similar cultural roots especially their cosmologic belief namely siwalima. Siwalima is a belief that shapes natives' character; respecting the diversities because they are brother ".

Local wisdom is reflected through high cultural diversity where there are various languages and accents in Maluku which are divided into the same cultural roots, especially their cosmological beliefs, namely siwalima. Siwalima is a belief that forms native character; respect diversity because they are brothers.

In line with that, the public's perception that cultural values are used as local wisdom is the identity and existence of a community that is highly valued and upheld, so it can encourageindigenous people to always boast and maintain it (Titaley, Kanto, Wisadirana, \& Mardiyono, 2018). Even in the context of local culture, the tradition Pela-Gandong for the people of Maluku, especially in Central Maluku, is quite influential in their communities, so efforts to foster character from the younger generation can be done as early as possible to anticipate increasingly complex problems such as the low attention of the younger generation to the surrounding environment (Tuhuteru, 1991).

Looking at and considering the differences that exist among them kulutrul, social and religious differences, Pela-Gandong is a union between one country or several other countries on Ambon Island, Lease, and Seram Island that bases a true relationship with the content and conduct of the union regulated in agreements both oral and written, where the parties promise to submit to the agreement as a legal basis implemented from time to time (Aponno, Brasit, Taba, \& Amar, 2017).

In line with that there are various views and even research that always examines the relationship of Pela-Gandong as a study that has a very important effect in upholding togetherness and maintaining brotherly relations. Some of these views and research are always examined through various aspects and various disciplines. Say Pela-Gandong is studied from the aspect of anthropological sociology, scientific studies that are emphasized to prevent and deal with conflict, fostering post-conflict society, and developing development are even used for integration in educational methods.

Pela-Gandong also proved to be an interesting study for local, national, and even international researchers who think that Pela-Gandong is a local content that is used as a cultural model that is used as a call for the souls of strong Basbans, so that anything that becomes a burden and responsibility of the people of Basudara, it is also a shared responsibility. Besides that, Pela-Gandong is a local wisdom from the pattern of brotherhood that has proven to be effective in building a community system that is full of religious tolerance for a long time (Tangidy \& Setiawan, 2016).

In social integration Pela-Gandong was able to reconcile the brotherhood that had been hurt, but also as a cultural friendship that has institutionalized in every heart, mind, and behavior of the people of Maluku, namely that they come from the same culture even though the religion is different (Attamimy, 2014).

Based on understanding Pela-Gandong's of several research studies presented, the concept Pela-Gandong in the development of social integration education as a local content, in general, is more directed to a set of plans and arrangements regarding the purpose, content and material of learning prepared by the education unit in accordance with diversity of regional potential, regional characteristics, regional superiority, regional needs, and their respective environments and the methods used to guide learning activities to achieve certain educational goals.

Local content is also interpreted as an educational program whose content and media are related to the natural, social, and cultural environment and the local development needs that need to be taught to students. But in reality, local content is seen as class number two and is only a supplement. In the case of actual local content, it can be interpreted as all potentials and works of an area which are natural and human resources found in an area (Marliana; Hikmah, 2013).

Determination of content and learning material for local content based on environmental conditions and needs as outlined in subjects with stand-alone time allocation. Specifically, it is intended to show that local content is an educational program in the form of subjects whose content and media are related to the natural environment, social environment, and cultural environment and regional needs that must be learned by students in the area.

The process of developing local content is then used as the basis for efforts to shape national character by expanding the depth of local content which consists of various types of local content as a step to introduce and foster a love for regional culture (Nafisah, 2016: 461).

The concept of based social integration education Pela-Gandong- as a local 
content, is intended as a model of local culture that can be used as learning material that is deliberately designed according to the development of the model taken. It aims to provide students with the knowledge, skills, attitudes, and behavior so that they have broad, creative insights about the state of the environment and the needs of the community so that later students are able to develop and preserve local cultural wisdom based on their characteristics.

The wisdom of the local culture here is the concepts, ideas, and ideas of local culture that are wise and used as a view of the life of the local community. The importance of planting local culture in education is to instill the identity and identity of the nation's people who are noble and virtuous (Oktavianti et al, 2017: 36).

This educational material on social integration was adapted from the forms of brotherhood from social institutions in the local wisdom of culture which then focused on the way of life of the Basudara people, the role of Pela-Gandong, the culture Pela-Gandong in traditional traditions in Maluku. These materials will then be elaborated in the structure of achieving goals, namely; 1) Cultural diversity in Maluku, 2) Togetherness in diversity Pela-Gandong, 3) Grateful for Pela-Gandong Diversity. The third achievement of this goal can be integrated in the process of developing learning so that there is a maintenance of patterns of cultural values and local wisdom that is owned.

The development of local content study material is determined by the education unit and is not limited to skills subjects which aim to provide knowledge, skills and behavior to students so that they have a solid insight into the state of the environment and the needs of the community in accordance with the values or rules that apply in the regions and supporting regional development (Muktadir \& Agustrianto, 2014).

Local content is oriented to competencies which has implications for the development of local wisdom based on content standards, process standards, and assessment standards set by the government. Thus, each education unit must develop competency standards and basic competencies for each type of local content developed based on the applicable curriculum.

In Indonesia, the use of curricula in national education today, known as the 2013 curriculum. This curriculum uses an integrated or integrated thematic learning approach, in which learning is integrated based on various competencies from various subjects into various themes. The basic competencies in learning local content in this 2013 curriculum are related to the arts, culture, skills, and regional languages that are integrated in the subjects of Culture and Craft, while other local content can be linked to the subjects of PPKn, IPS, Science, Indonesian or PJOK (Prastowo, 2014:9).

This integrated thematic learning approach is related to flexibility, fusion of student learning, reflection of the real world, and alignment of ways of thinking. Flexibility here implies the use of time and can be tailored to the needs of students, the integration of student learning is related to the process of integrating the understanding of convergence while preventing inconsistencies between subjects, real-world reflection intends to reflect the experienced real world in terms of thinking based on by research that concludes that students receive many things and summarize them into one (Utami \& Suyitno, 2016).

In addition, thematic learning displayed in the 2013 curriculum provides flexibility for teachers to create their own themes as long as it is relevant and effective in the learning process in terms of themes that are binding tools and strategies of learning, not replacing learning goals as stated in graduate competency standards, competencies core, and basic competencies.

The objectives of this integrated thematic learning are: a) focusing learning on a theme, b) studying and developing various competencies in the same theme, c) increasing understanding of subject matter in depth and impressing, d) developing language competencies that are associated with students' personal experiences, e) agitated learning by communicating in the real world, f) interpreting learning in the context of life with a real theme, g) saving time because subjects are presented in an integrated manner, $h$ ) character and morals of students developing in accordance with situations and conditions actually (Anwar et al, 2017).

The learning implementation is supported by textbooks which are one type of printed teaching material that utilizes a variety of local arts and cultures as learning or can be used as a theme of learning. In this regard, the based social integration education model is Pela-Gandong- sought by the author as an implementation of the development of locally-charged learning materials that can be delivered by the teacher to students through the learning process.

Based on the 2013 curriculum, the development of this model was developed in integrated thematic learning materials based on local wisdom in grade IV SD with the theme "The Beauty of Togetherness Pela-Gandong" which learning materials can be used by teachers and students as a form of learning local culture in order to revitalize Pela-Gandong as the social integration education model which is currently being promoted by the Maluku regional government in an effort to preserve, preserve and preserve cultural values as the indigenous tradition of the Moluccas.

\section{Methodology/Materials}

\section{A. Methodology}

The method used in this study is the method of research and development or Research and Development (R \& D), with a qualitative approach. The development research model is a process used to develop and validate educational products such as syllabus, learning material, textbooks, learning methods, and others that are carried out in a cycle of research and development (Borg and Gall,1983).

Based on focus research and development, the research method is used to produce locally-charged thematic learning material products that can integrate local wisdom values which will later be used as enrichment and can be used by

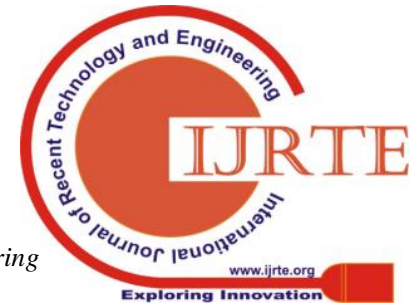


teachers and students as textbooks or textbooks. This research was carried out at SD Inpres Latta, Baguala Ambon-Maluku Subdistrict with the research subject in grade IV elementary school students.

The procedure used in this study is the ADDIE Learning Design

Model

(Analysis-Design-Develop-Implement-Evaluate) which in the preliminary study used a preliminary step from the Borg and Gall learning model as a reference for the initial research procedure or preliminary research. The reason for using this method is because the researcher sees the advantages of a systematic working procedure besides the effectiveness and efficiency associated with the final evaluation, but there are also revisions that are usually carried out throughout the process in accordance with the small-scale analysis and evaluation carried out at the end of each stage. The process of data collection is done using interview instruments and questionnaire instruments using the Likert scale to measure the opinions of students and experts.

\section{B. Data Analysis Techniques Data}

Analysis techniques refer to qualitative data obtained from suggestions, criticism, and input from experts, students and teachers to revise locally charged teaching materials Pela-Gandong developed by researchers. While quantitative data is used to analyze the score results from the validation sheet of experts / experts, to analyze the validity of the product to be used.

Validity analysis in this case the product developed is done by collecting expert validation data to assess the validity of the teaching material developed by the researcher in full of material experts, design experts, media experts, and linguists, whose validity is presented using formulas :

$\mathrm{P}=\sum \mathrm{x} \quad \mathrm{x} 100 \%$

$\sum x i$

Description:

P: Percentage

$\sum x$ : Total number of answers in all items

$\sum x i$ : The total number of ideal values in all items

100: Kostanta

Determination of product criteria developed as a learning media is feasible if the percentage of validity is more than $61 \%$ (Arikunto, 2008:35), so that the product can be used as learning material in grade IV of elementary school. The level of achievement and quality of feasibility can be seen in the following table:

Table 1 Level of Achievement and Quality of Feasibility

\begin{tabular}{cc}
\hline Achievement Score & Product Quality \\
\hline $81-100 \%$ & Very Good \\
$61-80 \%$ & Good \\
$41-60 \%$ & Enough \\
$21-40 \%$ & Less \\
$<21 \%$ & Less Once \\
\hline
\end{tabular}

\section{RESUltS AND FINDINGS}

\section{A. Stage of Development of Pela-Gandong-Based Social Integration Education Model as Local Content of Learning}

Based on the results of preliminary research which includes identification of needs, interviews, and literature studies of observations made in schools, the results show that much needed learning material can be used as a source learning is locally charged for students and learning guidelines for teachers who can display a history of culture and tradition that has been developing in the community as a tool of transformation and revitalization to strengthen brotherly relations in Maluku.

The results of this preliminary study later became a reference in designing and developing the based social integration education model Pela-Gandong- as a local content that can be applied in elementary schools. On the basis of thinking that the concept of based social integration education Pela-Gandong- can be used as a model of local culture which is intentionally designed based on a blend of elements of culture and tradition that exist in Maluku society, which aims to provide knowledge, skills and attitudes that are appropriate for students based on cultural elements that have been integrated, so that students have a broad insight into the local wisdom of the culture of their own region.

Furthermore, in the development phase, the model that has been designed must be developed in accordance with basic competency mapping in sub-themes and in learning that will be developed into learning material products, which are arranged into thematic learning textbooks for students and teacher books in implementing teaching and learning in the classroom.

In line with that, the design of the development of this model is made by considering:

- Integrated thematic learning aspects in which the lessons to be delivered are adjusted to the 2013 curriculum, with local content to be delivered also adapted to cultural diversity in Maluku and presented thematically integrated so as not to separate per study area or per subject.

- The local content conveyed is based on the reality of people's lives in Maluku, especially in the development of based social integration education Pela-Gandong-. Where the cultural diversity of Pela-Gandong is seen as a cultural model of the kinship of the Basudara people in Maluku who care for each other, love each other, share and love one another.

The theme in this learning book was made as a reference for students and teachers in the teaching and learning process. The contents of the book compiled from the diversity of Maluku and the beauty of its history, to various traditional traditions as mentioned earlier, are packaged in such a way as to deepen students' knowledge and insight into their own culture. What is interesting about the diversity of cultures displayed is that it is

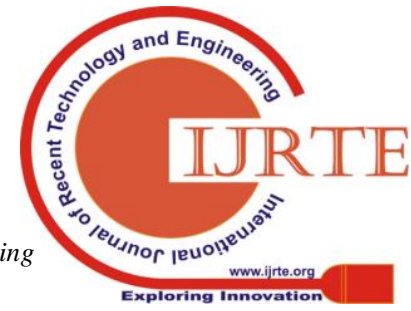


always related to the tradition Pela-Gandong.

\section{B. Impelmentation from the Level of Achievement and Quality of Product Feasibility Development of the Pela-Gandong-Based Social Integration Education Model As Learning Local Content}

In this section, the results of the level of achievement and quality of product feasibility are carried out through expert validation testing, which aims to see the learning material feasible developed by researchers in an effort to meet the needs of students for culture-based local content material in Maluku, which in this case is the development of based social integration education models Pela-Gandong- as local content in elementary schools. This product validation test will be carried out by design experts, media experts, material experts and grammar experts as described as follows:

\section{1) Validation Test Results From Experts}

From the results of the validation test of material experts, in this case material experts, media experts, design experts, and grammar experts, then the local content thematic learning materials product based social integration education Pela-Gandong- in themed elementary schools the beauty of Pela-Gandong togetherness results in the following data:

Table 2. Data Results ofMaterial

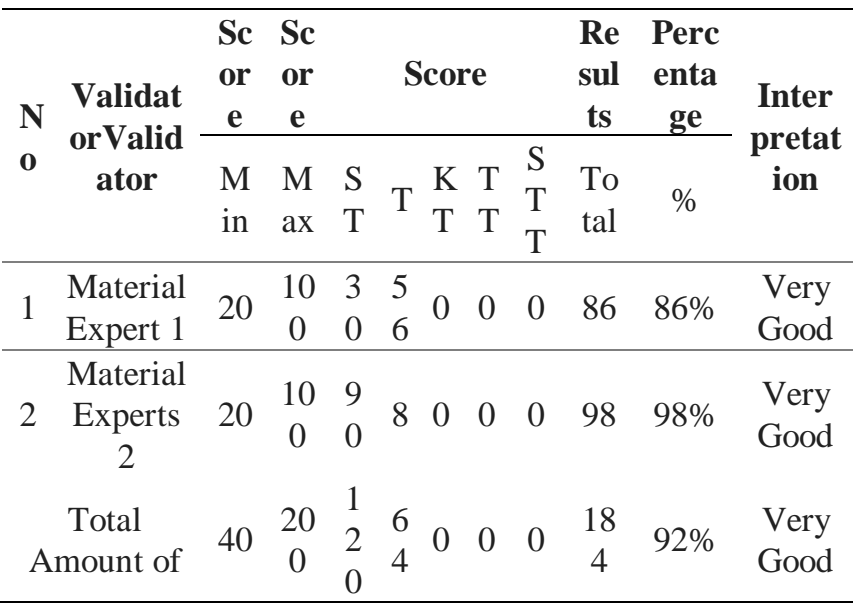

The results of the validation of two experts in this material, the results obtained for the first material experts $86 \%$ and the second expert $98 \%$. This means that the material from the aspects of competence and material content have been stated to be very good.

Table 3. Results of Validation Expert Design

\begin{tabular}{|c|c|c|c|c|c|c|c|c|c|c|}
\hline \multirow{2}{*}{$\begin{array}{l}\mathbf{N} \\
\mathbf{0 .}\end{array}$} & \multirow{2}{*}{$\begin{array}{l}\text { Valid } \\
\text { ator }\end{array}$} & $\begin{array}{l}\text { Sco } \\
\text { res }\end{array}$ & $\begin{array}{l}\text { Sco } \\
\text { res }\end{array}$ & Scor & $\mathbf{S} \mathbf{R}$ & esul & llts & $\begin{array}{l}\text { Res } \\
\text { ults }\end{array}$ & $\begin{array}{l}\text { Perce } \\
\text { ntage }\end{array}$ & \multirow{2}{*}{$\begin{array}{l}\text { Interpr } \\
\text { etation }\end{array}$} \\
\hline & & Min & $\begin{array}{c}\mathbf{M a} \\
\mathbf{x}\end{array}$ & $\begin{array}{l}\mathbf{S} \\
\mathbf{T}\end{array}$ & $\begin{array}{l}\mathbf{K} \\
\mathbf{T}\end{array}$ & $\begin{array}{l}\mathbf{T} \\
\mathbf{T}\end{array}$ & $\begin{array}{c}\text { ST } \\
\text { T }\end{array}$ & & $\begin{array}{c}\text { Total } \\
\%\end{array}$ & \\
\hline 1 & $\begin{array}{c}\text { Exper } \\
\mathrm{t} \\
\text { Desig } \\
\mathrm{n} 1\end{array}$ & 22 & 100 & $\begin{array}{ll}2 & 72 \\
0 & 72\end{array}$ & 0 & 0 & 0 & 92 & $92 \%$ & $\begin{array}{l}\text { Very } \\
\text { Good }\end{array}$ \\
\hline & Exper & & & & & & & & & \\
\hline 2 & $\begin{array}{c}\mathrm{t} \\
\text { Desig } \\
\mathrm{n} 2\end{array}$ & 22 & 100 & $\begin{array}{l}4 \\
0\end{array} 56$ & 0 & 0 & 0 & 96 & $96 \%$ & $\begin{array}{l}\text { Very } \\
\text { Good }\end{array}$ \\
\hline & $\begin{array}{l}\text { Total } \\
\text { Total }\end{array}$ & 44 & 200 & $\begin{array}{lc}6 & 12 \\
0 & 8 \\
\end{array}$ & 0 & 0 & 0 & 188 & $94 \%$ & $\begin{array}{l}\text { Very } \\
\text { Good }\end{array}$ \\
\hline
\end{tabular}

The results of the design expert validation on the development of the based social integration education model Pela-Gandong- that refers to the systematic aspects and teaching materials, get the results of the first expert $92 \%$ and the results of the second expert $96 \%$. This indicates that the interpretation of the two experts on the learning design assessment is said to be very good.

Table 4. Results of Validation Expert Media

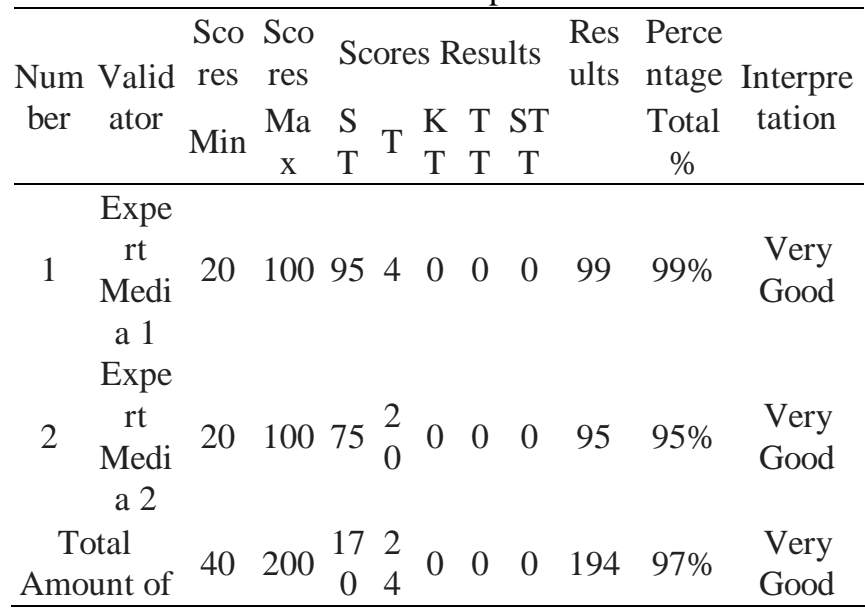

Validation of media experts in relation to media developed in thematic learning of local content Beautiful Pela-Gandong Togetherness shows that in the aspect of learning media the resulting interpretation gets results for the first expert $99 \%$ validity and the second expert is $95 \%$, has shown that the interpretation of learning media is very good. This means that the media developed is very valid, and provides good benefits for students and teachers both in its use and in understanding the content of the material to be delivered and the quality of the comprehensive presentation of learning with local thematic models Pela-Gandong that can provide a positive assessment for students and teachers as users of these products.

Table 5. results Validation Expert Grammar

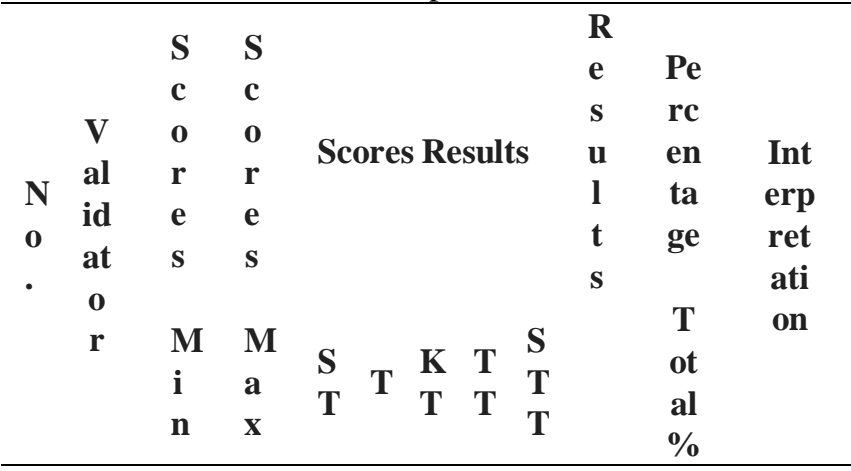




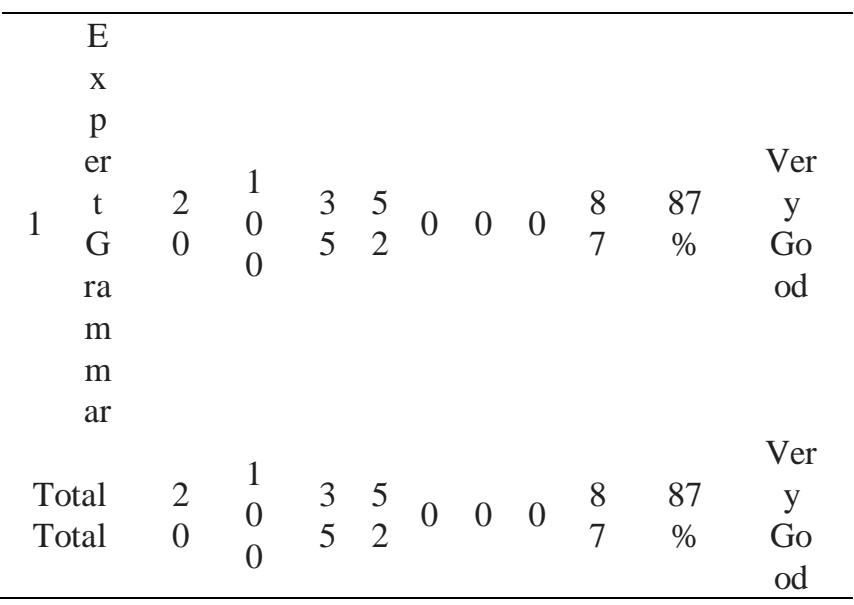

The results of the validation of grammar experts regarding the product development ofbased social integration education model Pela-Gandong- as local content refers to the systematic indicators of writing, word selection and sentence preparation, language use, letter usage, readability, and use of diction from local grammar aspects, with the results shown $87 \%$ of the level of validity with very good interpretation. This means that the validation of grammar experts shows very valid results for the products to be used, both in the use of diction or the choice of words that are balanced in the local content typical of Maluku culture, even so in terms of the terms of the language in the area.

\section{2) Trial One to One}

In this stage, information about the material, display, readability of the material, and assignments, even aspects of the suitability of the image with content, letter accuracy, image clarity, accuracy in choosing the material in each lesson, and color accuracy are considered. The steps that can be taken in the test are one to one choosing 3 students based on their ability categories, namely: 1) Students who have high abilities, students who have moderate abilities, and students who have low abilities, 2) Determine one of the learning materials from in teaching materials that will be developed to students to be seen and read, and then students will be given oral questions to answer.

The results of thetest one to one from the students' answers that: 1) the aspect of content or material, shows the appearance is interesting, the content is more open insight into student knowledge, easy to read and understand. 2) aspects of the media ranging from images, illustrations to the use of letters and colors, showing students who stated clearly, related to images of sub-themes and each learning, and the use of letters and colors, making it easier for students to understand what was read and what he learned.

\section{3) Small Group Trial (Small Group)}

In a small group test, students who are used as a trial sample consist of 12 students with high, medium, and low abilities. The results of the small group test refer to the questionnaire format which was made in the form of questions totaling 12 items with the operational choices being Very Exact $(\mathrm{ST})=5$, Exact $(\mathrm{T})=4$, Inappropriate $(\mathrm{KT})=3$, Incorrect $(\mathrm{TT})=2$, and Very Inaccurate $(\mathrm{STT})=1$.

The results of the questionnaire describe the views of students on the questions in the indicators related to the appearance of the book which states very precisely (ST) the number of empirical scores is 180 while precisely $(\mathrm{T})$ the empirical score of the students 'answers is 96 with the presentation value $87 \%$ indicating that the students' empirical answers the appearance of the teaching materials is very good. that means it's already very good and decent in terms of appearance. This can be seen in the following table.

Table 6.Data Test Results for Small Groups

\begin{tabular}{|c|c|c|c|c|c|c|c|c|}
\hline \multirow{2}{*}{\multicolumn{2}{|c|}{$\begin{array}{cc}\mathbf{N} & \text { Indic } \\
\mathrm{o} & \text { ators }\end{array}$}} & $\begin{array}{l}\text { Num } \\
\text { bers }\end{array}$ & $\begin{array}{c}\text { Sc } \\
\text { or } \\
\text { e }\end{array}$ & $\begin{array}{c}\text { Sc } \\
\text { or } \\
\text { e }\end{array}$ & $\begin{array}{c}\text { Student } \\
\text { Answers } \\
\text { (empirical } \\
\text { score) }\end{array}$ & $\begin{array}{l}\text { Nu } \\
\text { mbe }\end{array}$ & $\begin{array}{c}\text { Perce } \\
\text { ntage } \\
\text { s }\end{array}$ & \multirow{2}{*}{$\begin{array}{c}\text { Interp } \\
\text { retatio } \\
\mathbf{n}\end{array}$} \\
\hline & & Item & $\begin{array}{c}\mathrm{Mi} \\
\mathrm{n}\end{array}$ & $\begin{array}{c}\mathrm{Ma} \\
\mathrm{X}\end{array}$ & $\begin{array}{lllll}\mathrm{S} & \mathrm{T} & \mathrm{K} & \mathrm{K} \\
\mathrm{T} & \mathrm{T} & \mathrm{T} & \mathrm{T}\end{array}$ & $r$ of & $\%$ & \\
\hline
\end{tabular}

\begin{tabular}{|c|c|c|c|c|c|c|c|c|c|c|c|c|}
\hline 1 & $\begin{array}{l}\text { Displa } \\
\text { y book }\end{array}$ & $\begin{array}{c}1,2,3 \\
4,5\end{array}$ & 60 & $\begin{array}{c}30 \\
0\end{array}$ & $\begin{array}{l}1 \\
8 \\
0\end{array}$ & $\begin{array}{l}9 \\
6\end{array}$ & 0 & & 0 & 276 & $87 \%$ & $\begin{array}{l}\text { Very } \\
\text { Good }\end{array}$ \\
\hline 2 & $\begin{array}{c}\text { Conte } \\
\text { nts of } \\
\text { Mater } \\
\text { ial } \\
\text { presen } \\
\text { ted }\end{array}$ & $\begin{array}{l}6,7,8 \\
9,10\end{array}$ & 60 & $\begin{array}{c}30 \\
0\end{array}$ & $\begin{array}{l}2 \\
5 \\
0\end{array}$ & $\begin{array}{l}4 \\
0\end{array}$ & 0 & & 0 & 290 & $96 \%$ & $\begin{array}{l}\text { Very } \\
\text { Good }\end{array}$ \\
\hline 3 & $\begin{array}{c}\text { Learni } \\
\text { ng } \\
\text { effecti } \\
\text { veness }\end{array}$ & $\begin{array}{l}11 \\
12\end{array}$ & 24 & $\begin{array}{c}12 \\
0\end{array}$ & $\begin{array}{l}9 \\
0\end{array}$ & $\begin{array}{l}2 \\
4\end{array}$ & & 0 & 0 & 114 & $95 \%$ & $\begin{array}{l}\text { Very } \\
\text { Good }\end{array}$ \\
\hline & $\begin{array}{l}\text { Total } \\
\text { mount }\end{array}$ & 12 & $\begin{array}{c}14 \\
4\end{array}$ & $\begin{array}{c}72 \\
0\end{array}$ & $\begin{array}{l}5 \\
2\end{array}$ & $\begin{array}{l}1 \\
6 \\
0\end{array}$ & 0 & 0 & 0 & 680 & $94 \%$ & $\begin{array}{l}\text { Very } \\
\text { Good }\end{array}$ \\
\hline
\end{tabular}

Furthermore the results of the trial data developed in the development of the local content thematic learning model Beautiful Pela-Gandong Togetherness, for the content of the material presented, shows that the students' answers to the content presented are very precise (ST) 250 empirical scores and exact (T) scores empirical 40 with presentation numbers obtained is $96 \%$ illustrating that interpreting the contents of the material presented is very good and feasible to be used to increase students' knowledge and learning insights regarding the local wisdom of Maluku culture through thematic local content Beautiful Pela-Gandong Togetherness. Whereas when viewed from the indicators of learning effectiveness, the results of filling in student questionnaires in small group trials, getting an empirical score for very precise (ST) 90 and appropriate (T) is 24 with the presentation obtained is $95 \%$ can be interpreted very well, so it is clear once that the effectiveness of the thematic local content learning process Beautiful Pela-Gandong Togetherness is worthy of being used.

This small group trial was carried out after revisions from experts, andtrials one to one, so that in the revisions in this small group trial, only minor revisions were made around the addition of explanations of regional language words as presented in thematic teaching materials local content Beautiful Pela-Gandong Togetherness. Thus, at the stage of field trials, the products made are feasible to use and can be implemented by students and

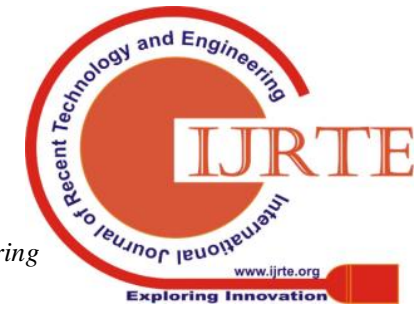


teachers as a source of learning.

\section{Conclusion}

Based on the research process that has been done, it can be concluded that:

- $\quad$ The research on the development ofbased social integration education model Pela-Gandong- as a local content, basically refers to the procedure of developing learning models and the combination of structural functional theory to analyze the social system of the culture and traditions of the people in Maluku, so that they can display concepts and sub-themes that can used as local learning material at school.

The procedure of developing thisbased social integration education model Pela-Gandong- is a combination of the Borg and Gall model as a preliminary study which includes needs analysis, observation, literature study and ADDIE Model which includes steps namely; Analysis, design, development, implementation and evaluation. With the final results of the research procedure the development of thematic learning models of local content is adapted so that it becomes a learning guide that conceptually and practically describes the thematic learning of local content Beautiful Pela Gandong Togetherness, as a cultural tradition that can be revitalized and transformed well to students as cultural models need to be maintained and preserved.

The results of field tests on the development model of local content thematic learning materials the beauty of the PelandongGathering shows significant results and is feasible to be used as locally charged learning materials in schools. This can be seen from the results of expert validation tests andtests one to one and small groups that are shown to students, with the hope that the size of this local content textbook is not only used in class IV but can also be implemented in other classes. reference for the development of local content learning models at the secondary school level.

\section{ACKNOWLEDGEMENTS}

This research work is supported by the Ministry of Research, Technology, \& Higher Education, Republic of Indonesia

\section{REFERENCES}

[1] Anwar, R. (2017). Hal-Hal Yang Mendasari Penerapan Kurikulum 2013. Humaniora. Https://Doi.Org/10.21512/Humaniora.V5i1.2987

[2] Aponno, E. H., Brasit, N., Taba, M. I., \& Amar, M. . (2017). Factors That Influence Organizational Citizenship Behavior and Employees Performance " Pela Gandong ". Scientific Research Journal (Scirj), V(Vi), 10-26.

[3] Arikunto, S. (2008). Metode Penelitian.

[4] Attamimy, M. (2014). Pela- Gandong And Harmonization Life of Brotherhood (Orang Basaudara) (Study Case the Relations of Islam And Christianity Post Conflict in Ambon) M. Al-Ulum, 14(2), 275-294.

[5] Chandra. (1992). No Title.

[6] Dewi, O. (2007). Konsep Dasar Keberadaan Masyarakat Dan Terbentuknya Integrasi Sosial. Informasi Kajian Permasalahan Sosial Dan Usaha Kesejahteraan Sosial.

[7] Gustafson, K. L., \& Branch, R. M. (2002). Survey of Instructional Development Models. New York: Eric Clearinghouse on Information \& Technology.

[8] Hadi Riwayati Utami, \& Suyitno. (2016). Relevansi Tema Kurikulum 2013 Sekolah Dasar Muatan Lokal - Nasional. Malih Peddas, 6.
Retrieved

from

Http://Journal.Upgris.Ac.Id/Index.Php/Malihpeddas\%0arelevansi

[9] Hasanah, N., Ulfatin, N., \& Wiyono, B. B. (2017). Local Wisdom “ Hidop Orang Basudara "Within the Perspective of Teachers ' Competence in Smpn 1 Tehoru, Central Maluku District, Maluku Province Indonesia, 22(10), 19-27. Https://Doi.Org/10.9790/0837-2210031927

[10] Instructional Design : (N.D.).

[11] Judiani, S. (2018). Implementasi Pendidikan Karakter Di Sekolah Dasar Melalui Penguatan Pelaksanaan Kurikulum. Jurnal Pendidikan Dan Kebudayaan. Https://Doi.Org/10.24832/Jpnk.V16i9.519

[12] Manuhuttu, R., Purwiyastuti, W., \& Widiarto, T. (2009). Budaya Pela Gandong Di Negeri Haria Sebagai Alat Pemersatu Dan Perdamaian Orang Maluku Tengah, 3-4.

[13] Marliana; Hikmah, N. (2013). Pendidikan Berbasis Muatan Lokal Sebagai Sub Komponen Kurikulum. Jurnal Dinamika Ilmu, 13(1), 105-119.

[14] Marliana, \& Hikmah, N. (2013). Pendidikan Berbasis Muatan Lokal Sebagai Sub Komponen Kurikulum. Dinamika Ilmu, 13(1), 105-119. Https://Doi.Org/Http://Dx.Doi.Org/10.21093/Di.V13i1.68

[15] Muktadir, A., \& Agustrianto. (2014). Jurnal Pendidikan Karakter. Pengembangan Model Mata Pelajaran Muatan Lokal Berbasis Kearifan Lokal Untuk Meningkatkan Karakter Di Sekolah Dasar Provinsi Bengkulu, Tahun Iv, 318-331.

[16] Nafisah, D. (2016). Peran Pendidikan Muatan Lokal Terhadap Pembangunan Karakter Bangsa. Jurnal Pancasila Dan Kewarganegaraan, 4, No. 2, 451-468. Retrieved from Http://E-Journal.Unipma.Ac.Id/Index.Php/Citizenship/Article/View/10 78/942

[17] Prastowo, A. (2014). Paradigma Baru Madrasah Dalam Implementasi Kebijakan Kurikulum 2013. Jurnal Pendidikan Islam. Https://Doi.Org/10.14421/Jpi.2014.31.95-113

[18] Raiser, R. A., \& Jhon V. Damsay. (2007). Trend and Issues in Instructions Desaign And Technology. Boston: Person Education, Inc.

[19] Richey, R. C., Klein, J. D., \& Tracey, M. W. (N.D.). The Instructiona Design Knowledge Base: Theory, Research, And Practice. Taylor And Francis.

[20] Rosana, E. (2011). Modernisasi Dan Perubahan Sosial. Jurnal Tapis. Https://Doi.Org/10.24042/Tapis.V7i1.1529

[21] Smaldino, E. Sharon, Lowthe, L. R. D., \& Russel, D. J. (2011). Instructional Technology and Media for Learning 9th Edition:Terjemahan Arif Rahman. In Instructional Technology and Media for Learning 9th Edition:Terjemahan Arif Rahman (9th Ed.). Jakarta: Kencana Prenada Media Group.

[22] Smith, T. O., Hedges, C., \& Schankat, K. (2010). A Systematic Review of The Rehabilitation of Liss Plate Fixation of Proximal Tibial Fractures. Advances in Physiotherapy, 12(2), 100-110 Https://Doi.Org/10.3109/14038190902906326

[23] Tangidy, A. M., \& Setiawan, T. A. (2016). Toleransi Melalui Model Budaya Pela Gandong Menggunakan Media Board Game Untuk Mahasiswa. Sabda Volume 11, Nomor 2, Desember 2016 Issn 1410-7910 E-Issn 2549-1628, 11(45), 39.

[24] Titaley, E., Kanto, S., Wisadirana, D., \& Mardiyono. (2018). Pela Dan Gandong Culture as Basic of a Network Formation for Poverty Alleviation in The Village. Advances in Social Sciences Research Journal, 5(3). Https://Doi.Org/10.14738/Assrj.53.4247

[25] Triyanto. (2014). Pendidikan Seni Berbasis Budaya. Imajinasi: Jurnal Seni, Viii(1), 33-42. Retrieved from Https://Journal.Unnes.Ac.Id/Nju/Index.Php/Imajinasi/Article/View/887 9/5818

[26] Tuhuteru, L. (1991). Efektifitas Pembinaan Karakter Generasi Muda Dalam Presepsi Tokoh Masyarakat Dan Pemuda (Studi Kasus Pasca Konflik Sosial Ambon).

[27] Watloly, A. (2012). Memperkuat Falsafah Hidup Orang Basudara. In Karel Albert Ralahalu "Berlayar Dalam Ombak, Berkarya Bagi Negeri: Pemikiran Anak Negeri Untuk Maluku ".

[28] Wedan, M. (2016). Pengertian Pendidikan Dan Tujuan Pendidikan Secara Umum.

[29] Weil, M., \& Joice, B. (1978). Social Models of Teaching; Expanding Your Teaching Repertaire. New Jersey: Prentice Hall Inc, Englewood Cliffs. 


\section{AUTHOR'S PROFILE}

Beatrix J.M. Salenussa from Post-Graduation Departmen of Educational Technology Universitas Negeri Jakarta and Lecturer at Universitas Kristen Indonesia Maluku. My area of interest education.

Suriani a Profesor at Universitas Negeri Jakarta. My area of interest is research and development.

Yufiati a Profesor at Universitas Negeri Jakarta. My area of interest is social science.

Nova M. Mataheru a Teacher at SMA Negeri 11 Ambon - Maluku. My area of interest is education. 